\title{
The past, present and future management of sickle cell retinopathy within an African context
}

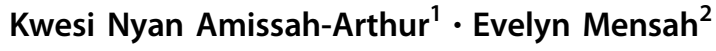

Received: 14 March 2018 / Revised: 19 May 2018 / Accepted: 28 May 2018 / Published online: 10 July 2018

(c) The Royal College of Ophthalmologists 2018

\begin{abstract}
Sickle cell retinopathy is a potentially blinding condition that affects young people in the working age group. This review looks at the past, present and future management of sickle cell retinopathy within an African context. After Sickle cell disease was first reported in 1910, some reports from Africa were pivotal in describing the retinal changes associated with the disease. It soon became obvious that there was a varied clinical picture and clinical course. Several landmark studies were carried out in Jamaica to help elucidate the complexities of the disease and outline appropriate clinical management. In most of the developed world, the clinical management of sickle cell disease has improved with concurrent improvement in outcomes. Currently resource constraints in most Sub-Saharan African countries where there is a high burden of disease means that the management of sickle cell retinopathy is fraught with numerous challenges. Future large scale trials in Africa shall hopefully help to better elucidate the mechanisms behind proliferative sickle retinopathy and help in the development of new and improved therapeutic pathways. The use of technology can help immensely in the screening of patients with sickle cell to detect early proliferative changes and if necessary treat accordingly.
\end{abstract}

\section{Introduction}

Sickle cell disease (SCD) was first described in Africa under a variety of names that related to cultural spiritual beliefs $[1,2]$. James B. Herrick was an American physician who made the first clinical discovery and reported in 1910 'peculiar elongated and sickle-shaped red blood corpuscles in a case of severe anaemia' affecting a medical student from Grenada [3]. Initially the disease was known as Herrick's syndrome and it was not until 1922 when a fourth case reported by a medical student, Verne R. Mason, from Johns Hopkins Hospital that the term 'sickle cell anaemia (SCA)' was first used [4].

Kwesi Nyan Amissah-Arthur

kaarthur@doctors.net.uk

1 Ophthalmology Unit, Department of Surgery, Korle Bu Teaching Hospital, College of Health Sciences, School of Medicine and Dentistry, University of Ghana, Accra, Ghana

2 Ophthalmology Department, Central Middlesex Hospital, London North West University Healthcare NHS Trust, London NW10 7NS, UK

\section{Genetics of SCD}

SCD is an autosomal recessive disorder of haemoglobin $(\mathrm{Hb})$, caused by inheritance from both parents of an altered $\beta$-globin chain gene of which one is at least haemoglobin S. The sickle allele is caused by a single point mutation where the amino acid valine is substituted for glutamic acid at the sixth position of the $\beta$-globin chain on chromosome 11 [5]. The most common and severe subtype of SCD worldwide is homozygous SS disease which is also referred to as SCA $[6,7]$. Heterozygous disorders of SCD arise due to coupling of the sickle gene with another haemoglobinopathy such as haemoglobin $\mathrm{C}$, where there is structural abnormality of the haemoglobin (HbSC). HbSC, is the second commonest subtype of SCD in West Africa, particularly among people from Burkino Faso and Northern Ghana [8, 9]. Beta thalassaemia, which comprises abnormalities of $\mathrm{Hb}$ production can also give rise to a heterozygous disorder of SCD known as $\mathrm{HbS} \beta^{0}$-thalassaemia when no normal $\beta$ chains are produced or $\mathrm{HbS}^{+}$-thalassaemia when reduced amounts of normal $\beta$ chains are produced, although this is rarely found in sub-Saharan Africa [10]. The carrier state for haemoglobin $\mathrm{S}$ is known as HbAS or sickle cell trait and is not considered to be a form of SCD [11]. Hb in red blood cells is responsible for oxygen transport throughout the body. 
During the deoxygenation process, red blood cells that contain haemoglobin $\mathrm{S}$, polymerise and become distorted changing from the normal round disc shape into a sickle shape. The sequelae of these rigid and inflexible sickle shaped red blood cells is occlusion of small blood vessels and anaemia as the abnormal cells are easily destroyed and removed from the circulation. Complications such as painful crisis and chronic organ damage leads to significant morbidity and early mortality [12].

High carrier status within the sub-Saharan African region and interaction with malaria is responsible for increased prevalence. Inheritance of the abnormal sickle gene protects against Plasmodium falciparum, a severe form of malaria [13]. The abnormal sickle cell gene has been mapped geographically to associated areas of endemic malaria [9]. SCD and sickle cell trait is prevalent in low-altitude equatorial regions such as sub-Saharan Africa and central India where malaria is prevalent $[13,14]$. Whilst sickle cell trait provides some defence against falciparum malaria early in childhood during a vulnerable stage, SCD offers no such protection against the associated life threatening disorders and death [14].

\section{Epidemiology of SCD}

Whilst SCD was originally a disease that was prevalent in tropical and subtropical regions, forced migration and ongoing population movement has now made it a global problem [15]. Worldwide, there are more than 400,000 children born each year with SCD with $84 \%$ of cases originating from sub-Saharan Africa making it one of the most ubiquitous genetic disorders [16, 17]. Estimated birth rates reach 10.68 per 1000 in Africa, 0.68 per 1000 in South and Southeast Asia, 0.49 per 1000 in the Americas and 0.07 per 1000 in Europe [17]. Within continental regions, there is a large variability in the prevalence of sickle cell trait. Although $7 \%$ of the world population are carriers of the abnormal sickle gene [18], it is reported in $1-38 \%$ in some parts of Africa, 0-29\% in Eastern Mediterranean, 7-30\% in India and affects $8 \%$ of African descents in the United States of America (USA) and the Caribbean conferring an immense disease burden $[19,20]$.

\section{Burden of SCD}

Common complications of SCD include chronic acute pain syndromes, severe bacterial infections, tissue necrosis and thromboembolic disease. This can subsequently affect growth and development. Although SCD is associated with major morbidity, in the developed world more than $90 \%$ of children with SCD survive into adulthood [21-23]. The median life expectancy is 42 years for men and 48 years for women compared with the mean life expectancy of two or three decades more compared with the general population [24, 25]. Evidence from cross-sectional population surveys and cohort studies suggests that mortality among children born in sub-Saharan Africa with SCD ranges from 50 to $90 \%$ [7, 20, 26-29]. Recognising this tremendous burden of SCD in sub-Saharan Africa, the WHO recommended in 2006 and 2010 that governments should implement effective strategies to ensure that SCD was included in their health care policies $[30,31]$. The interventions proposed included increased awareness, early diagnosis and improving the healthcare for affected individuals. Inspite of this, to date, SCD remains a relatively neglected disease in the African continent [8]. The reasoning being that genetic diseases, such as SCD are not considered to be an immediate priority when infectious disease and malnutrition are a major cause of morbidity. Many cases of early mortality from SCD are misdiagnosed as secondary to malaria or infections further compounding the problem of lack of reliable data [8]. Although there is enough evidence to justify investments in screening, prophylaxis and treatment for children with SCD in sub-Saharan African, more realiable data is still required to estimate the numbers of child deaths preventable by such interventions and their cost effectiveness.

\section{Sickle cell retinopathy}

Pathology of the anterior and posterior segment of the eye can occur in any individual with SCD. Retinal disease occurs more frequently and is considered to have greater morbidity due to the risk of sight impairment from vascular occlusion and subsequent ischaemia [32, 33]. The sight threatening sequelae of sickle cell retinopathy (SCR) arise due to the release of tissue factors that stimulate neovascular growth $[34,35]$. Thereby SCR is classified as either nonproliferative or proliferative.

\section{Prior understanding of SCR}

In 1937, Harden [36] published the first retinal findings of SCR in two patients who had dilated and tortuous vessels which were at that time attributed to congenitally abnormal vessels. The next case series came from Accra, in what was then the Gold Coast, describing unusual changes in retinal vessels with peripheral small aneurysms in one case and vitreous haemorrhage in the other which was the first allusion to a specific retinopathy [37]. It is interesting to note that the subsequent published case reports of SCR were all related to vitreous haemorrhage $[38,39]$. Welch and 
Goldberg [40, 41] published a landmark case control study of 143 patients to document and categorise all the retinal findings for this condition [41]. This classification is still in practice today. The natural course of the 'incipient' stage of SCR was poorly understood. A longitudinal study performed by Galinos et al. was the first time that remodelling of the peripheral retinal vasculature was documented [42]. Although the proliferative stage was better understood, it produced some therapeutic challenges, especially as a number of proliferative cases were known to spontaneously regress or auto-infarct [43].

\section{Early studies}

Most of the early work carried out was observational, which helped to document the various fundus findings of venous tortuosity, lipid deposits, obliterated arterioles and venules, retinitis proliferans, sea fans, black sunburst, vitreous haemorrhage and retinal detachments [41] as well as classify $[40,44]$ them accordingly. One of the hallmarks of Proliferative Sickle cell Retinopathy (PSR) are Sea fans. These are extra-retinal neovascularisations that subsequently become fibrovascular and tend to begin peripherally. The term sea fan is a synonym of the term retinitis proliferans which was used in earlier literature [40, 41, 44]. Early on it was noted by Goldberg that the natural history of SCR was variable in disease progression and severity [45]. Observational studies found that $\mathrm{HbSC}$ was associated with a greater degree of sea fans and PSR than HbSS [46]. It was also found that peripheral retinal pathology was more common in HbSC disease compared to HbSS and it could progress with age [47, 48]. A set of longitudinal cohort studies carried out in Jamaica from 1973 to 1981 were the earliest set of studies to look at sickle cell in a longitudinal fashion and have been the mainstay of evidence for SCR to date. They concurred that proliferative SCD was progressive after a 30 month study [44, 48]. One of the reports from the Jamaican cohort looked at 54 children with HbSC disease on the register of the University Hospital of West Indies between the ages of 2 and 15 and found that although there were no ocular symptoms, the fundus was abnormal in all but two cases. Retinitis proliferans was present in $11 \%$ of cases [48]. Another study on the same cohort indicated that retinal vascular disease changes occur before the age of 6 in both HbSS and HbSC disease [49]. With regards to adults, 98.5\% were noted to have peripheral retinal vessel disease and $32 \%$ were found to have retinitis proliferans [50]. They showed that bilateral proliferative sickle retinopathy occurred in $49 \%$ of $\mathrm{HbSS}$ patients and $70 \%$ of $\mathrm{HbSC}$ patients $[44,50]$. The risks associated with progression to proliferative disease in the Jamaican cohort included HbSC disease, where males aged between 15 and 24 and females aged between 20 and 39 had the highest risk of progression. In HbSS disease it was between 25 and 39 years of age in both sexes. The haematological risk factors in HbSS disease were a high $\mathrm{Hb}$ in males and a low foetal $\mathrm{Hb}$ in both sexes. In $\mathrm{HbSC}$ disease a high mean cell volume and a low foetal $\mathrm{Hb}$ in females [51]. Despite all the evidence showing PSR in these cohorts, visual loss appears to be infrequent. The main reason for this is the well documented phenomenon of regression of neovascular lesions [43, 52]. Having said that, when vision loss occurs it is significant and can lead to blindness with Condon and Serjeant reporting $12 \%$ of blindness in their untreated cohort [52]. The main causes of visual loss are vitreous haemorrhage and tractional retinal detachment, although epiretinal membranes can also cause significant visual morbidity [32, 43, 52]. The rate of vision loss in untreated eyes has been estimated at 31 per 1000 eye-years observation amongst eyes with proliferative disease and 1.4 per 1000 eye-years observation amongst eyes with non-proliferative disease [32]. Even though Africa and in particular West Africa has the highest burden of SCD [53], there has been a paucity of data on SCR. Most of the published work from Africa have been retrospective or cross-sectional studies with very few cohort or longitudinal studies [54-58]. One of the earliest case series in 1978 of HbSS disease in children from a sickle centre clinic at the Lagos University Teaching Hospital found retinal lesions in $58 \%$ of cases. The series was unable to comment on peripheral retinal lesions given the absence of fluorescein angiography [59]. A series that looked at HbSC disease reported similar findings to the Jamaican Cohort studies [60]. PSR was found to be present in $26 \%$ of cases in a retrospective case series from Togo [61].

\section{Preventive treatment regimes}

Given the progressive nature of SCR and the potential for visual loss due to vitreous haemorrhages and retinal detachments, Hannon in 1956 attempted scleral surface diathermy of retinitis proliferans associated with PSR [62]. The initial results were favourable, unfortunately there was no long term follow up available [62]. Diathermy was further investigated by Condon and Serjeant with good initial results, and a report of one disastrous complications of anterior segment ischaemia [63]. The use of cryotherapy to close sea fans has been shown to be effective, however, complications of retinal tears and tractional retinal detachments (22\%) can occur [64]. The role of laser photocoagulation in the treatment of SCDs was not clearly defined due to the poor understanding of factors involved in the progression and regression of PSR [52]. Given the fact that this was a retinal vascular disease, it was not surprising that laser treatment and diathermy were felt to be a potential treatment modality that could prevent progression of 
PSR [63, 65]. Goldberg reported on the use of xenon arc photocoagulation on 15 patients with a $74 \%$ success rate in causing vascular occlusion of sea fans [66]. Argon laser photocoagulation was used to either occlude the feeding artery posterior to the neovascular lesion or obliterate the entire neovascular lesion. In an early study by Goldberg and Acacio, a $97 \%$ success rate in vascular occlusion of sea fans was reported [65]. This study found a vitreous haemorrhage rate of $14 \%$ either immediately or after 1 week, with a lower amount of visual field loss when compared with xenon arc photocoagulation [65]. Condon and Serjeant managed to treat 131 out of 137 neovascular lesions with vitreous haemorrhage occurring in one eye using a xenon arc photocoagulator [63]. Early on it was recognised that feeder vessel coagulation was a difficult technique and that there was the potential to cause choroido-retinal and choroido-vitreal neovascular lesions [67]. Jampol et al performed a randomised clinical trial that looked at feeder vessel photocoagulation and noted that despite the complications of choroidal neovascularisation [68] there was a significant decrease in the incidence of vitreous haemorrhage and vision loss from vitreous haemorrhage [69]. Given the complications and difficulties associated with feeder vessel photocoagulation, scatter laser was thought to be safer and offer similar benefits. The technique involves scatter laser treatment to the area or sector of the neovascular lesion [70]. Kimmel et al. have reported on their favoured technique of peripheral circumferential scatter laser coagulation which showed a complete regression rate of $33 \%$ and a partial regression rate of $46 \%$ with $19 \%$ remaining stable and $2 \%$ progressing [71]. Farber et al. designed the first randomised control trial that looked at local scatter photocoagulation around the area of proliferative sickle retinopathy and found complete or partial regression of sea fans in $81.2 \%$ of the initially treated sea fans and complete closure in $30.2 \%$, whereas in the control eyes the numbers were as follows, spontaneous regression in $46 \%$ and complete auto-infarction in $22.4 \%$ [70]. Retinal detachment was reported in $3 \%$ of eyes treated by scatter photocoagulation and $10.6 \%$ of the control group [70]. These two clinical trials have been the only published trials on laser photocoagulation for SCR to date.

\section{Surgical management}

The development of non-clearing vitreous haemorrhages, tractional or rhegmatogenous or combined detachments causes significant visual morbidity in this relatively young group of patients [32, 45, 52]. Other complications that cause visual loss in this group of patients are epiretinal membranes and macular holes [72]. These require surgical intervention either with conventional cryo-buckle surgery or pars plana vitrectomy surgery. Cryo-buckle surgery was initially the mainstay of treatment of retinal detachments. It was used with relative success for some detachments secondary to SCD [73-75]. However, one of the most devastating complications related to cryo-buckle surgery is anterior segment ischaemia with the incidence appearing to be higher in sickle cell patients. The risk of its occurrences is exacerbated by detaching extra-ocular muscles or the use of extensive retinopexy around the ciliary vessels [75, 76]. This complication which was reported in $71 \%$ of cases by Ryan and Goldberg is essentially irredeemable if severe and causes almost certain devastating visual loss [76].

The use of vitrectomy for the management of the complications of SCR was clear to the early proponents of vitreous surgery. The relief of severe vitreous traction that complicated retinal detachments was very attractive to those who had suffered complications of encircling bands in the management of these cases [77]. Complications include cataract formation, iatrogenic retinal breaks, anterior segment ischaemia, recurrent vitreous haemorrhage and secondary glaucoma [78, 79]. Given the difficulty with endoillumination and visualisation, early on in the genesis of vitrectomy surgery, there was a difficulty of safely accessing the vitreous base. This was reflected in the first case series by Jampol et al. where visual improvement in vitrectomy technology resulted in more favourable outcomes where one case series reported good results $80 \%$ of eyes with tractional retinal detachment [79]. Several of the early case series, report the use of scleral buckles in conjunction with vitrectomy to mitigate some of the difficulties and risks of inadequate visualisation [79, 80]. Over time the technology associated with vitrectomy improved with more routine use of endoillumination, endodiathermy and endolaser. A case series of four patients with vitreous haemorrhage or retinal detachment secondary to PSR was very promising with no serious complications [81]. A retrospective case series from St Thomas' Hospital in London showed that with the advent of more modern vitrectomy techniques the complication rate in their series of 27 eyes was low [82]. This conclusion was echoed by Chen et al. in their retrospective interventional case series [83].

\section{Present}

Currently there is no worldwide consensus on the best management of SCR. This is partly due to lack of high quality evidence pertaining to systematic screening and lack of robust prevalence data, particularly in sub-Saharan Africa.

\section{Screening for SCR and SCD}

Screening is designed to reduce the risk or impact of disease in a defined population [84]. To date there are no 
randomised controlled trials evaluating the role of retinal screening in people with SCD. In addition no studies have evaluated the optimal screening test or screening interval. Most reports described are longitudinal studies that are either observational, cross sectional or retrospective.

The Jamaican Cohort Study [33] was a 20-year, prospective longitudinal, observational study of 474 people with HbSS [307] and HbSC [166]. Annual fundus examination through dilated pupils was described although the exact method used was not specified. All individuals had annual fluorescein angiography and angioscopy. The age range was from 5 to 26 years old. PSR was defined as leakage of blood vessels on fluorescein angiography or angioscopy. PSR occurred at a younger age in $\mathrm{HbSC}$ (8 years old) compared with HbSS (16 years old) patients. There was increased incidence of PSR with increasing age with $43 \%$ of subjects with $\mathrm{HbSC}$ and $14 \%$ of subjects with HbSS by ages 24 and 26 years, respectively. Although the authors indicated that spontaneous regression of PSR occurred in $32 \%$ and visual loss was rare, one must interpret the results with caution. The peak age group for development of PSR is 20 to 39 years [51]. The participants in this Jamaican Cohort Study were relatively young since the maximum age at last retinal examination was 26 years. In addition the definition of regression was vague.

Moriarty et al. [32] conducted in Jamaica a 10 year, prospective, longitudinal, observational trial of the control (fellow) eyes of patients that had been previously enroled in a randomised control trial assessing the effect of laser treatment on PSR.

All other patients that entered the trial had both eyes included. Individuals had at least two eye examinations at least three months apart during the study period. The patients were aged from 15 years to 60 years with 120 patients suffering from HbSS and 222 with HbSC. All eyes were examined with direct and indirect ophthalmoscopy through dilated pupils. Fundus photography and fluorescein angiography were performed where appropriate. The study observed visual loss attributable to SCR in $10 \%$ of untreated eyes during a mean follow-up period of 6.9 years

In 2008, Gill and Lam [85] published retrospective, longitudinal, survival analysis on 263 Canadian children with SCD referred to an ophthalmology service in a hospital over 18 years. All children were under 18 years of age and included 163 with $\mathrm{HbSS}, 73$ with $\mathrm{HbSC}$ and 27 with $\mathrm{HbS} \beta$ thalassaemia. All children had annual dilated funduscopic examinations although the method used was not described. Fluorescein angiography was only performed if PSR was suspected. They found that PSR was $8.2 \%$ in $\mathrm{HbSC}, 0.6 \%$ in $\mathrm{HbSS}$ and there were no cases in $\mathrm{HbS} \beta$-thalassaemia. Overall the mean age of onset of clinically significant PSCR was 14.0 years (median 13 years, range $9-18$ years). The authors recommend that screening for SCR begin at age 9 years for
$\mathrm{HbSC}$ patients and at 13 years for $\mathrm{HbSS}$ and $\mathrm{HbS} \beta$ thalassaemia patients. They suggested that serial examinations may be done biannually for eyes with normal findings, and that fluorescein angiography be performed on eyes with abnormal examinations, with follow up as necessary.

An expert panel under the auspices of the National Heart, Lung and Blood Institute convened in 2014 to issue guidelines aimed to assist health care professionals in the management of acute and chronic complications and comorbidities of SCD [86]. They recommended that from age 10, any person with SCD is referred to an ophthalmologist for a dilated eye examination to evaluate for retinopathy. They also recommended re-screening at 1 to 2 years intervals for any person with a normal dilated retinal examination and referral to a retinal specialist for people with suspected retinopathy.

Screening for SCR should aim to detect patients at risk from lesions that require further specialised examination, investigation and treatment. In literature there has been very little discussion about the ideal screening method for detecting SCR. Whilst it is suggested that individuals are referred to an ophthalmologist for a dilated fundus examination [86], ideally this should be indirect ophthalmoscopy using a slit lamp or head mounted ophthalmoscope and a condensing fundus lens. Since pathology preferentially affects the peripheral retina, it is essential that the pupils are dilated. The disadvantage of ophthalmoscopy is the lack of a permanent record which means that there is no form of quality assurance. An ideal screening tool would be digital photography. Most fundus cameras acquire images that are $45-50^{\circ}$ degree in dimensions which means that full retinal coverage would require up to seven images captured per eye as used in the Early Treatment Diabetic Retinopathy Study. Taking seven standard fields is time consuming, technically difficult to do and would still only cover up to $75^{\circ}$ of the retinal field [87]. Wide field photography has the potential to image $200^{\circ}$ of the retinal field in one single frame [84]. The limiting factor for wide field photography is the high cost of the camera. In practical terms, fluorescein angiography is not a good screening method and is best used as a diagnostic tool.

Whilst SCD is associated with significant morbidity, in developed countries more than $90 \%$ of children live into adulthood and the survival rate has been steadily increasing [21-23]. In contrast, mortality attributed to SCD remains high in sub-Saharan Africa with more than 50\% dying before the age of 5 years old with the cause of death attributed to secondary infection or severe anaemia [8]. Simple public health actions, such as a neonatal screening programme for SCD and parent education can have a significant effect on survival for children living in developing countries [26] Thus far there are few African countries that are able to offer newborn screening since the cost involved in setting up a programme has been the limiting factor for the majority $[19,88]$. 


\section{Medical management of SCD and SCR}

Improved medical care and new approaches to treatments have contributed to the survival of people with SCD [89-91]. Although there is no definitive cure for SCD, hematopoietic stem cell transplantation (formerly known as bone marrow transplantation) is showing promise but is expensive and only available to a limited number of compatible people [92]. Disease modifying drugs such as hydroxyurea increase the production of foetal $\mathrm{Hb}$ which reduces the tendency for red blood cells to sickle and reduces the production of white blood cells that contribute to inflammation. In well-resourced countries, hydoxyurea, is the standard of care for controlling vaso-occlusive complications [86]. There is evidence to suggest that treatment with hydroxyurea may offer protection from SCR [93]. Blood transfusions are also an important part of managing complications associated with SCD [86]. Indeed there are a number of case reports describing the effect that exchange transfusion has on the treatment of SCR by reducing sickle $\mathrm{Hb}$ [94, 95]. Challenges faced by a number of lower resourced countries able to deliver such therapies include lack of physicians trained to use hydroxyurea, fears and misconceptions about the side effects as well as the unavailability of blood and the safety of blood products [96]. Added factors that make management of the person with SCD difficult in sub-Saharan Africa are poor hygiene, malnutrition and infectious diseases such as malaria. However, a few African countries have demonstrated that simple measures such as prophylaxis and prompt treatment of bacterial infections and malaria together with pain control can improve morbidity and mortality [97, 98]. Improving the general healthcare of babies will result in longer survival and the ability of children with SCD to present for diagnosis and treatment [19]. Inevitably there will be a demographic shift in many sub-Saharan countries over the next 20 years. This means that health agencies and governments have to plan for the future and implement programmes for the management of acute and chronic complications of haemoglobinopathies.

Ultimately the effectiveness of a routine screening programme for SCR must be assessed as well as the benefits of blood transfusions and hydroxyurea therapy as preventive treatments for the development of SCR.

\section{Use of laser}

There are two randomised control trials (RCTS) that have demonstrated the benefit of laser photocoagulation as a treatment for PSR compared with observation alone in reducing rates of visual loss and decreasing the incidence of vitreous haemorrhage $[69,70]$. In spite of this there are some ophthalmologists that do not treat PSR such as sea fans with scatter laser. This is because the authors were only able to show a significant difference in regression of PSR in people younger than 25 years and in small, flat sea fans [99]. In addition an observational study has reported a $32 \%$ rate of spontaneous regression of PSR [33]. It is possible that the RCTs were too under-powered to demonstrate any non-inferiority of laser as a primary outcome measure [100]. Whilst there is no consensus, laser photocoagulation tends to be done when there is bilateral PSR, large elevated seafans, rapid growth of sea-fans, when there is associated vitreous haemorrhage, or in cases where there is loss of vision in the fellow eye from PSR [101, 102]. The application of laser appears to be either sectoral where areas of sea fans are surrounded or 360-degree circumferential peripheral scatter photocoagulation $[69,70]$. The latter may be considered in a poorly compliant patient. In either case it is important to consider other options if there is associated vitreo-retinal traction since laser could result in retinal breaks or detachment [103]. In Africa, particularly Sub Saharan Africa, access to retinal laser treatment in general has been very limited and patchy with only a few specialised centres having access to laser machines [104]. There have been no publications from Sub Saharan Africa on the use of retinal laser in the management of PSR.

To date there are no prospective randomised control trials assessing the effect of early laser prophylaxis. The aim would be to apply targeted scatter laser to areas of capillary non-perfusion identified on fundus fluorescein angiography [105]. The proposed effect would be to reduce the release of vascular endothelial growth factors responsible for stimulating the growth of neovascular tissue. Despite scatter laser treatment for established PSR, new areas of sea fans can develop in up to $34 \%$ of eyes [70].

Further research is required to determine the role that screening and early laser treatment play in the management of SCR. It is important to identify whether targeted prophylactic scatter laser treatment prevents development of PSR and whether new sites of vessels arise in areas of capillary non-perfusion not previously treated with targeted scatter laser.

\section{Use of anti-VEGF}

The angiogenic factor, vascular endothelial growth factor (VEGF) is associated with sea-fan formation in PSR $[34,35]$. Intravitreal anti-vascular endothelial growth factor agents are widely used to treat a variety of neovascular conditions such as choroidal neovascular membranes [106]. More recently anti-VEGF agents have been evaluated in clinical trials as treatment for proliferative diabetic retinopathy to determine whether there is non-inferiority to 
standard laser treatment $[107,108]$. There are a few reports in the literature that describe the use of anti-VEGF drugs to treat PSR [109-111]. There are also a number of cases which report the use of pre-operative intravitreal anti-VEGF agents as an adjunct to vitreo-retinal surgery to aid segmentation and dissection of fibrovascular tissues under minimal bleeding conditions and to reduce the risk of postoperative bleeding $[112,113]$. Although the case reports describe regression of retinal neovascularisation and reduced duration of vitreous haemorrhage, randomised controlled clinical trials are needed to further clarify the role of intravitreal anti-VEGF agents in the management of PSR. In sub Saharan Africa there are a few reports that describe the use of intravitreal anti-VEGF agents such as Bevacizumab as an adjunct to clear vitreous haemorrhage prior to the application of laser treatment [114]. Indeed, there is logic for using anti-VEGF agents as intravitreal treatment for the regression of sea fans and vitreous haemorrhage. This could potentially avoid the need for laser or vitreoretinal surgery; the latter of which is expensive or unavailable in many developing countries. However, there is apprehension about using anti-VEGF agents in this manner because of the theoretical associated risk that increased fibrosis could occur and cause a tractional retinal detachment as observed when treating proliferative diabetic retinopathy [115].

\section{Improving surgical outcomes}

Whilst significant visual loss in SCD is predominantly due to the complications of PSR, namely vitreous haemorrhage and retinal detachment, in recent years there has been much advancement in vitreoretinal techniques that allows safer surgery. Small gauge pars plana vitrectomy has more or less replaced scleral buckling. Shorter operating times and wider viewing systems have all contributed to reducing the risk of inflammation and anterior segment ischaemia previously associated with vitreoretinal surgery in people with SCD. In spite of this, there is paucity of reports pertaining to the use of vitreoretinal surgery in the management of PSR. The management of vitreous haemorrhage in PSR when there is no associated retinal detachment is to observe for a period of time to determine spontaneous resolution [79, 101]. In fact in certain circumstances, it has been suggested that in cases where there is tractional retinal detachment, this can also be observed without risk of progression [82]. The use of vitrectomy in Sub-Saharan Africa has been limited due to low resources and lack of skilled manpower [116]. Maneh et al. looked at the risk factors for retinal detachments in Togo and found that patients with SCD accounted for $16 \%$ of cases that presented with retinal detachments [117].
Today there are still unanswered questions about how best to manage the patient with PSR. We need to establish how we can achieve the best visual outcome for the patient. Whether this is with conservative management, laser photocoagulation, vitreoretinal surgery or intravitreal antiVEGF agents in addition to identifying the optimal time to apply each strategy can only be determined by employing large scale clinical trials.

\section{The future}

The management of SCR from an African context has to take a multifaceted approach. To effectively understand the disease process it is imperative that large multi-centre African based trials with long-term follow up in the mould of the human heredity and health in Africa kidney disease [118] are performed. These prospective trials have to be innovatively designed to answer several questions that have come up in this review paper such us: what are the genetic modifiers and environmental determinants that cause progression of SCR; is there a way to better predict disease severity; how can we better risk stratify patients; when is the optimal point to perform prophylactic laser treatment; are there better strategies to be employed when operating on the complications of SCR [119]. These large clinical studies have to be designed with strong basic science components, that will look at not just the red blood cell component of the disease but the other extrinsic causes, particularly the inflammatory, procoagulant, vasculopathic and angiogenic causes [12]. A large amount of work has been done on therapeutic options for SCD in general [120], moving forward it will be important to clearly ascertain the assessment of how these therapies affect SCR. There has been promising curative results from allogenic haemotopeitic stem-cell transplantation [121], however only a small number of patients have access to a matched donor. There has been recent interest in the use of gene therapy, either by gene editing [122] or vector mediated gene therapy [123]. These studies are very promising and have mostly taken place in developed countries, however the low resource levels of several African countries makes its wholesale adoption difficult in the part of the world that is most burdened by SCD [124].

\section{Clinical management}

There has been a tremendous advancement in the hospital management of complications of SCR and the management of PSR in the developed world. In Africa, particularly Sub-Saharan Africa and other developing economies there has been a large deficit in the ability to adequately 
investigate and treat retinal pathology [116, 125, 126]. This is one area where, if adequate attention is paid to train and equip some key centres the outcomes of PSR can be much improved [127]. Currently most of the gains in management of SCD in Africa are regarding the prevention and treatment of infections [128]. The move towards prevention of end organ damage has begun but an incomplete understanding of SCR combined with a low resource setting has made the management of this blinding complication difficult. The use of safe, appropriate and affordable solutions in the management of SCR are required to improve the visual prognosis in patients with retinal complications. Telemedicine and virtual ophthalmology clinics [129] have the opportunity to change how low resource countries tackle retinal diseases. In the context of imaging and screening of the retina, there is a move towards image based screening using wide field fundus photography [84, 129]. Recent advances in OCT technology have shown that early retinal thinning [84, 130] and foveal avascular zone changes seen on OCTA [130, 131] may be effective ways of selecting those at greater risk of progression to proliferative sickle cell retinopathies. The future use of these imaging technologies in association with automated screening of retinal images $[131,132]$ could firstly reduce the reliance on manpower and secondly improve the early detection of proliferative retinopathy. These technologies have the potential to change the future management of this condition in Africa, however, the high capital cost of OCT and OCTA have so far made the wholesale adoption of these fantastic tools challenging.

After the early detection of proliferative retinopathy, it is imperative that patients requiring treatment are able to access it to prevent long term morbidity [133]. This requirement for laser or vitreoretinal surgery is currently difficult to obtain for the vast majority of people in SubSaharan Africa [126]. There is the need to train and upskill ophthalmologists with an interest in retina to be able to perform these therapies. Given the reduced manpower resources in several African countries, innovative sandwich style programmes that allow doctors to become upskilled in the management of sickle retinopathy without leaving their main base of work for too long are required. There is then the need for countries with a higher prevalence of these complications to invest in equipment that shall allow these patients to be treated safely and competently [116].

\section{Conclusion}

SCR is a potentially blinding condition that affects young people in the working age group. This paper has reviewed the past, present and future management of SCR in Africa. It is clear that the developed world has moved towards preventing target organ damage in the management of SCD. Unfortunately in the continent where there is the greatest burden of disease and disability, resource constraint means that many young people are blinded by this disease. Improvement in the outcomes of the management of SCD are yet to fully be realised with regards to SCR. Future large scale trials in Africa shall hopefully help to better elucidate the mechanisms behind proliferative sickle retinopathy and help in the development of new and improved therapeutic pathways. The use of technology can help immensely in the screening of patients with sickle cell to detect early proliferative changes and if necessary treat accordingly. Given the increase in migration of Africans to developed countries, it is also beneficial for these countries to forge partnerships to further improve the understanding and management of SCR.

Acknowledgements We are grateful to Rushmia Karim and Parth Shah for reviewing the manuscript.

\section{Compliance with ethical standards}

Conflict of interest The authors declare that they have no conflict of interest.

\section{References}

1. Nzewi E. Malevolent ogbanje: recurrent reincarnation or sickle cell disease? Soc Sci Med. 2001;52:1403-16.

2. Onwubalili J, Sickle-cell anaemia: an explanation for the ancient myth of reincarnation in Nigeria. Lancet. 1983;322:503-5.

3. Herrick JB. Peculiar elongated and sickle-shaped red blood corpuscles in a case of severe anemia. JAMA. 2014; 312:1063-1063.

4. MASON VR. Sickle cell anemia. J Am Med Assoc. 1922;79:1318-20.

5. INGRAM VM. Abnormal human haemoglobins. III. The chemical difference between normal and sickle cell haemoglobins. Biochim Biophys Acta. 1959;36:402-11.

6. PAULING L. Molecular disease and evolution. Bull N Y Acad Med. 1964;40:334-42.

7. Rees DC,Williams TN,Gladwin MT, Sickle-cell disease. Lancet. 2010;376:2018-31

8. Grosse SD, Odame I, Atrash HK, Amendah DD, Piel FB, Williams TN. Sickle cell disease in Africa: a neglected cause of early childhood mortality. Am J Prev Med. 2011;41:S398-405.

9. Piel FB, Patil AP, Howes RE, Nyangiri OA, Gething PW, Williams TN, et al. Global distribution of the sickle cell gene and geographical confirmation of the malaria hypothesis. Nat Commun. 2010;1:104-104.

10. Fleming AF, Storey J, Molineaux L, Iroko EA, Attai ED. Abnormal haemoglobins in the Sudan savanna of Nigeria. I. Prevalence of haemoglobins and relationships between sickle cell trait, malaria and survival. Ann Trop Med Parasitol. 1979;73:161-72.

11. Serjeant GR. Sickle-cell disease. Lancet. 1997;350:725-30. 
12. Madigan C, Malik P. Pathophysiology and therapy for haemoglobinopathies. Part I: Sick Cell Dis Expert Rev Mol Med. 2006;8:1-23.

13. Aluoch JR. Higher resistance to Plasmodium falciparum infection in patients with homozygous sickle cell disease in western Kenya. Trop Med Int Health TM Ih. 1997;2:568-71.

14. Serjeant GR, Vichinsky E. Variability of homozygous sickle cell disease: the role of alpha and beta globin chain variation and other factors. Blood Cells Mol Dis. 2017. http://www. sciencedirect.com/science/article/pii/S1079979617301237

15. Davies SC,Brozovic M, The presentation, management and prophylaxis of sickle cell disease. Blood Rev. 1989;3:29-44.

16. Piel FB, Patil AP, Howes RE, Nyangiri OA, Gething PW, Dewi $\mathrm{M}$, et al. Global epidemiology of sickle haemoglobin in neonates: a contemporary geostatistical model-based map and population estimates. Lancet Lond Engl. 2013;381:142-51.

17. Modell B, Darlison M. Global epidemiology of haemoglobin disorders and derived service indicators. Bull World Health Organ. 2008;86:480-7.

18. Ashley-Koch AYQ, Olney RS. Sickle hemoglobin ( $\mathrm{HbS})$ allele and sickle cell disease: a HuGE review. Am J Epidemiol. 2000;151:839-45.

19. Ansong D, Akoto AO, Ocloo D, Ohene-Frempong K. Sickle cell disease: management options and challenges in developing countries. Mediterr J Hematol Infect Dis. 2013;5:e2013062.

20. Weatherall DJ, Clegg JB. Inherited haemoglobin disorders: an increasing global health problem. Bull World Health Organ. 2001;79:704-12.

21. Quinn CT, Rogers ZR, McCavit TL, Buchanan GR. Improved survival of children and adolescents with sickle cell disease. Blood. 2010;115:3447.

22. Artz N, Whelan C, Feehan S. Caring for the adult with sickle cell disease: results of a multidisciplinary pilot program. J Natl Med Assoc. 2010;102:1009-16.

23. Telfer P, Coen P, Chakravorty S, Wilkey O, Evans J, Newell H, et al. Clinical outcomes in children with sickle cell disease living in England: a neonatal cohort in East London. Haematologica. 2007;92:905.

24. Platt OS, Brambilla DJ, Rosse WF, Milner PF, Castro O, Steinberg MH, et al. Mortality in sickle cell disease. Life Expect risk Factors Early death N Engl J Med. 1994;330:1639-44.

25. Powars DR, Chan LS, Hiti A, Ramicone E, Johnson C. Outcome of sickle cell anemia: a 4-decade observational study of 1056 patients. Med (Baltim). 2005;84:363-76.

26. Serjeant GR. Mortality from sickle cell disease in Africa. BMJ. 2005;330:432

27. Makani J, Williams TN, Marsh K. Sickle cell disease in Africa: burden and research priorities. Ann Trop Med Parasitol. 2007;101:3-14.

28. Weatherall DJ. The inherited diseases of hemoglobin are an emerging global health burden. Blood. 2010;115:4331.

29. Diallo DA. Sickle cell disease in Africa: current situation and strategies for improving the quality and duration of survival. Bull Acad Natl Med. 2008;192:1361-72. discussion1372-73

30. WHO. WHO. Sickle Cell Disease: a strategy for the WHO Africa region. Report of the regional director. Document number AFR/ RC60/8. Geneva, Switzerland: World Health Organization, Regional Office for Africa; 2010.

31. World Health Organisation (WHO). Joint WHO/TIF Meeting on the control of haemoglobinopathies. Report of the seventh meeting of the WHO working group on the control of hereditary anaemias; 3-4 April 1994; Nicosia, Cyprus. Unpublished document WHO/HDP/TIF/HA/93.1. Geneva, 1994.

32. Moriarty BJ, Acheson RW, Condon PI, Serjeant GR. Patterns of visual loss in untreated sickle cell retinopathy. Eye Lond Engl. 1988;2(Pt 3):330-5.
33. Downes SM, Hambleton IR, Chuang EL, Lois N, Serjeant GR, Bird AC. Incidence and natural history of proliferative sickle cell retinopathy. Ophthalmology. 2005;112:1869-75.

34. Cao J, Mathews MK, McLeod D, Merges C, Hjelmeland L, Lutty G. Angiogenic factors in human proliferative sickle cell retinopathy. Br J Ophthalmol. 1999;83:838-46.

35. Kim SY, Mocanu C, Mcleod DS, Bhutto IA, Merges C, Eid M, et al. Expression of pigment epithelium-derived factor (PEDF) and vascular endothelial growth factor (VEGF) in sickle cell retina and choroid. Exp Eye Res. 2003;77:433-45.

36. Harden AS. Sickle cell anemia: changes in the vessels and in the bones. Am J Dis Child. 1937;54:1045-51.

37. Edington GM, Sarkies JWR. Two cases of sickle-cell anaemia associated with retinal microaneurysms. Trans R Soc Trop Med Hyg. 1952;46:59-62.

38. Isbey EK, Clifford GO, Tanaka KR. Vitreous hemorrhage associated with sickle-cell trait and sickle-cell hemoglobin-C disease. Am J Ophthalmol. 1958;45:870-9.

39. Kennedy JJ, Cope CB. Intraocular lesions associated with sicklecell disease. AMA Arch Ophthalmol. 1957;58:163-8.

40. Goldberg MF. Classification and pathogenesis of proliferative sickle retinopathy. Am J Ophthalmol. 1971;71:649-65.

41. Welch RB, Goldberg MF. Sickle-cell hemoglobin and its relation to fundus abnormality. Arch Ophthalmol. 1966; 75:353-62.

42. Galinos SO, Asdourian GK, Woolf MB, Stevens TS, Lee CB, Goldberg MF, et al. Spontaneous remodeling of the peripheral retinal vasculature in sickling disorders. Am J Ophthalmol. 1975;79:853-70.

43. Nagpal KC, Patrianakos D, Asdourian GK, Goldberg MF, Rabb M, Jampol L. Spontaneous regression (autoinfarction) of proliferative sickle retinopathy. Am J Ophthalmol. 1975; 80:885-92.

44. Condon PI, Serjeant GR. Ocular findings in homozygous sickle cell anemia in Jamaica. Am J Ophthalmol. 1972;73:533-43.

45. Goldberg MF. Natural history of untreated proliferative sickle retinopathy. Arch Ophthalmol. 1971;85:428-37.

46. Levine RA, Kaplan AM. The ophthalmoscopic findings in $\mathrm{c}+\mathrm{s}$ disease. Am J Ophthalmol. 1965;59:37-42.

47. Condon PI, Serjeant GR. Ocular findings of elderly cases of homozygous sickle-cell disease in Jamaica. Br J Ophthalmol. 1976;60:361-4

48. Condon PI, Gray R, Serjeant GR. Ocular findings in children with sickle cell haemoglobin $\mathrm{C}$ disease in Jamaica. Br J Ophthalmol. 1974;58:644-9.

49. Talbot JF,Bird AC,Serjeant GR,Hayes RJ, Sickle cell retinopathy in young children in Jamaica. Br J Ophthalmol. 1982;66:149-54.

50. Condon PI, Serjeant GR. Ocular findings in hemoglobin SC disease in Jamaica. Am J Ophthalmol. 1972;74:921-31.

51. Fox PD,Dunn DT,Morris JS,Serjeant GR, Risk factors for proliferative sickle retinopathy. Br J Ophthalmol. 1990;74:172-6.

52. Condon PI, Serjeant GR. Behaviour of untreated proliferative sickle retinopathy. Br J Ophthalmol. 1980;64:404-11.

53. Mabayoje JO. Sickle-cell anaemia; a major disease in West Africa. Br Med J. 1956;1:194-6.

54. Kaimbo Wa Kaimbo D, Ngiyulu Makuala R, Dralands L, Missotten L. Ocular findings in children with homozygous sickle cell disease in the Democratic Republic of Congo. Bull Soc Belge Ophtalmol. 2000;275:27-30.

55. Osafo-Kwaako A, Kimani K, Ilako D, Akafo S, Ekem I, Rodrigues $\mathrm{O}$, et al. Ocular manifestations of sickle cell disease at the Korle-bu Hospital, Accra, Ghana. Eur J Ophthalmol. 2011;21:484-9.

56. Elebesunu-Amadasu M, Okafor LA. Ocular manifestations of sickle cell disease in Nigerians; experience in Benin City, Nigeria. Trop Geogr Med. 1985;37:261-3. 
57. Obikili AG, Oji EO, Onwukeme KE. Ocular findings in homozygous sickle cell disease in Jos, Nigeria. Afr J Med Med Sci. 1990;19:245-50.

58. George IO, Sci SCJMM, 2012. Eye manifestations of children with homozygous sickle cell disease in Nigeria. https://www.interesjournals.org/articles/eye-manifestations-ofchildren-with-homozygous-sickle-cell-disease-in-nigeria.pdf https://www.interesjournals.org/abstract/eye-manifestationsof-children-with-homozygous-sickle-cell-disease-in-nigeria2391.html

59. Abiose A, Lesi FEA. Ocular findings in children with homozygous sickle cell anemia in Nigeria. J Pediatr Ophthalmol Strabismus. 1978;15:92-95.

60. Majekodunmi SA, Akinyanju OO. Ocular findings in homozygous sickle cell disease in Nigeria. Can J Ophthalmol J Can Ophtalmol. 1978;13:160-2.

61. Balo KP, Segbena K, Mensah A, Mihluedo H, Bechetoille A. Hemoglobinopathies and retinopathies in Lomé UHC. J Fr Ophtalmol. 1996;19:497-504.

62. Hannon JF. Vitreous hemorrhages*: associated with sickle cellhemoglobin C disease. Am J Ophthalmol. 1956;42:707-12.

63. Condon PI, Serjeant GR. Photocoagulation and diathermy in the treatment of proliferative sickle retinopathy. $\mathrm{Br} \mathrm{J}$ Ophthalmol. 1974;58:650-62.

64. Goldbaum MH, Fletcher RC, Jampol LM, Goldberg MF. Cryotherapy of proliferative sickle retinopathy, II: triple freezethaw cycle. Br J Ophthalmol. 1979;63:97-101.

65. Goldberg MF, Acacio I. Argon laser photocoagulation of proliferative sickle retinopathy. Arch Ophthalmol. 1973;90:35-44. Chic Ill 1960

66. Goldberg MF. Treatment of proliferative sickle retinopathy. Trans - Am Acad Ophthalmol Otolaryngol Am Acad Ophthalmol Otolaryngol. 1971;75:532-56.

67. Condon PI, Serjeant GR. Photocoagulation in proliferative sickle retinopathy: results of a 5-year study. $\mathrm{Br} \mathrm{J}$ Ophthalmol. 1980;64:832-40.

68. Condon PI, Jampol LM, Ford SM, Serjeant GR. Choroidal neovascularisation induced by photocoagulation in sickle cell disease. Br J Ophthalmol. 1981;65:192-7.

69. Jampol LM, Condon P, Farber M, Rabb M, Ophthalmology SF. A randomized clinical trial of feeder vessel photocoagulation of proliferative sickle cell retinopathy: I. Preliminary results. Elsevier. 1983;90:540-5. 1983

70. Farber MD, Jampol LM, of PFA, 1991. A randomized clinical trial of scatter photocoagulation of proliferative sickle cell retinopathy. archopht.jamanetwork.com.

71. Kimmel AS, Magargal LE, Stephens RF, Cruess AF. Peripheral circumferential retinal scatter photocoagulation for the treatment of proliferative sickle retinopathy: an update. Ophthalmology. 1986;93:1429-34.

72. Brazier DJ, Gregor ZJ, Blach RK, Porter JB, Huehns ER. Retinal detachment in patients with proliferative sickle cell retinopathy. Trans Ophthalmol Soc UK. 1986;105(Pt 1):100-5.

73. Freilich DB, Seelenfreund MH. Long-term follow-up of scleral buckling procedures with sickle cell disease and retinal detachment treated with the use of hyperbaric oxygen. Mod Probl Ophthalmol. 1977;18:368-72.

74. Goldberg MF, Jampol LM. Treatment of neovascularization, vitreous hemorrhage, and retinal detachment in sickle cell retinopathy. Trans New Orleans Acad Ophthalmol. 1983;31:53-81.

75. Eagle RC, Yanoff M, Morse PH. Anterior segment necrosis following scleral buckling in hemoglobin Sc disease. Am J Ophthalmol. 1973;75:426-33.

76. Ryan SJ, Goldberg MF. Anterior segment ischemia following scleral buckling in sickle cell hemoglobinopathy. Am J Ophthalmol. 1971;72:35-50.
77. Goldbaum MH, Peyman GA, Nagpal KC, Goldberg MF, Asdourian GK. Vitrectomy in sickling retinopathy: report of five cases. Ophthalmic Surg. 1976;7:92-102.

78. Treister G, Machemer R. Results of vitrectomy for rare proliferative and hemorrhagic diseases. Am J Ophthalmol. 1977;84:394-412.

79. Jampol LM, Green JL, Goldberg MF, Peyman GA. An update on vitrectomy surgery and retinal detachment repair in sickle cell disease. Arch Ophthalmol. 1982;100:591-3.

80. Pulido JS, Flynn HW, Clarkson JG, Blankenship GW. Pars plana vitrectomy in the management of complications of proliferative sickle retinopathy. Arch Ophthalmol. 1988;106:1553-7.

81. Morgan CM, D'Amico DJ. Vitrectomy surgery in proliferative sickle retinopathy. Am J Ophthalmol. 1987;104:133-8.

82. Williamson TH, Rajput R, Laidlaw DAH, Mokete B. Vitreoretinal management of the complications of sickle cell retinopathy by observation or pars plana vitrectomy. Eye. 2008;23:1314-20.

83. Chen RWS, Flynn HW Jr, Lee W-H, Parke III DW, Isom RF, Davis JL, et al. Vitreoretinal management and surgical outcomes in proliferative sickle retinopathy: a case series. Am J Ophthalmol. 2014;157:870-.e1.

84. Cho M, Kiss S. Detection and monitoring of sickle cell retinopathy using ultra wide-field color photography and fluorescein angiography. Retin Phila Pa. 2011;31:738-47.

85. Gill HS, Lam W-C. A screening strategy for the detection of sickle cell retinopathy in pediatric patients. Can J Ophthalmol J Can Ophtalmol. 2008;43:188-91.

86. National Heart, Lung, and Blood Institute. Evidence-based management of sickle cell disease: expert panel. 2014; 1-161.

87. ETDRS report number 10. Early Treatment Diabetic Retinopathy Study Research Group. 1991. Grading diabetic retinopathy from stereoscopic color fundus photographs - an extension of the modified airlie house classification. Ophthalmology. 1991; 98:786-806.

88. Tshilolo L, Kafando E, Sawadogo M, Cotton F, Vertongen F, Ferster A, et al. Neonatal screening and clinical care programmes for sickle cell disorders in sub-Saharan Africa: lessons from pilot studies. Public Health. 2008;122:933-41.

89. Gaston MH, Verter JI, Woods G, Pegelow C, Kelleher J, Presbury $\mathrm{G}$, et al. Prophylaxis with oral penicillin in children with sickle cell anemia. A randomized trial. N Engl J Med. 1986; 314:1593-9.

90. Adams RJ, McKie VC, Hsu L, Files B, Vichinsky E, Pegelow C, et al. Prevention of a first stroke by transfusions in children with sickle cell anemia and abnormal results on transcranial Doppler ultrasonography. N Engl J Med. 1998;339:5-11.

91. Adams, et al. Discontinuing prophylactic transfusions used to prevent stroke in sickle cell disease. N Engl J Med. 2005; 353:2769-78.

92. Freed J, Talano J, Small T, Ricci A, Cairo MS. Allogeneic cellular and autologous stem cell therapy for sickle cell disease: 'whom, when and how'. Bone Marrow Transplant. 2012; 47:1489-98.

93. Estepp JH, Smeltzer MP, Wang WC, Hoehn ME, Hankins JS, Aygun B. Protection from sickle cell retinopathy is associated with elevated $\mathrm{HbF}$ levels and hydroxycarbamide use in children. Br J Haematol. 2013;161:402-5.

94. Gustave BW, Oliver SCN, Mathias M, Velez-Montoya R, Quiroz-Mercado H, Olson JL, et al. Reversal of paracentral occlusive retinopathy in a case of sickle cell disease using exchange transfusion. Ophthalmic Surg Lasers Imaging Retina. 2013;44:505-7.

95. McKinney CM, Siringo F, Olson JL, Capocelli KE, Ambruso DR, Nuss R. Red cell exchange transfusion halts progressive proliferative sickle cell retinopathy in a teenaged patient with hemoglobin SC disease. Pediatr Blood Cancer. 2015;62:721-3. 
96. Schneider WH. History of blood transfusion in sub-saharan Africa. Transfus Med Rev. 2013;27:21-28.

97. Rahimy MC, Gangbo A, Ahouignan G, Adjou R, Deguenon C, Goussanou S, et al. Effect of a comprehensive clinical care program on disease course in severely ill children with sickle cell anemia in a sub-Saharan African setting. Blood. 2003;102:834-8.

98. Akinyanju OO, Otaigbe AI, Ibidapo MOO. Outcome of holistic care in Nigerian patients with sickle cell anaemia. Clin Lab Haematol. 2005;27:195-9.

99. Fox PD, Minninger K, Forshaw ML, Eye SV, 1993. Laser photocoagulation for proliferative retinopathy in sickle haemoglobin $\mathrm{C}$ disease. nature.com.

100. Myint KT, Sahoo S, Thein AW, Moe S, Ni H. Laser therapy for retinopathy in sickle cell disease. Cochrane Database Syst Rev. 2015;109:363-29.

101. Emerson GG, Harlan Jr. JB, Fekrat S, Lutty GA, Goldberg MF. Chapter 79 - Hemoglobinopathies A2 - Ryan, Stephen J. In: Hinton DR, Schachat AP, Wilkinson CP, editors. Retina (Fourth Edition). Edinburgh: Mosby; 2006. p. 1429-45. https://www. sciencedirect.com/science/article/pii/B9780323025980500859

102. Sayag D, Binaghi M, Souied EH, Querques G, Galacteros F, Coscas G, et al. Retinal photocoagulation for proliferative sickle cell retinopathy: a prospective clinical trial with new sea fan classification. Eur J Ophthalmol. 2008;18:248-54.

103. Jampol LM, Goldberg MF. Retinal breaks after photocoagulation of proliferative sickle cell retinopathy. Arch Ophthalmol. 1980;98:676-9.

104. Nwosu SN. Prevalence and pattern of retinal diseases at the Guinness Eye Hospital, Onitsha, Nigeria. Ophthalmic Epidemiol. 2000;7:41-48.

105. Jampol LM, Farber M, Rabb MF, Eye GS, 1991. An update on techniques of photocoagulation treatment of proliferative sickle cell retinopathy. nature.com.

106. Group CATTResearch, Martin, Maguire DF, Ying MG, Grunwald G, Fine JE. SL, et al. Ranibizumab bevacizumab neovascular ageRelat macular Degener N Engl J Med. 2011;364:1897-908.

107. Sivaprasad S,Prevost AT,Vasconcelos JC,Riddell A,Murphy $\mathrm{C}$, Kelly J, et al. Clinical efficacy of intravitreal aflibercept versus panretinal photocoagulation for best corrected visual acuity in patients with proliferative diabetic retinopathy at 52 weeks (CLARITY): a multicentre, single-blinded, randomised, controlled, phase $2 \mathrm{~b}$, non-inferiority trial. Lancet. 2017; 389:2193-203.

108. Le JT, Hutfless S, Li T, Bressler NM, Heyward J, Bittner AK, et al. Setting priorities for diabetic retinopathy clinical research and identifying evidence gaps. Ophthalmol Retin. 2017;1:94-102.

109. Mitropoulos PG, Chatziralli IP, Parikakis EA, Peponis VG, Amariotakis GA, Moschos MM. Intravitreal ranibizumab for stage IV proliferative sickle cell retinopathy: a first case report. Case Rep Ophthalmol Med. 2014;2014:6.

110. Shaikh S. Intravitreal bevacizumab (Avastin) for the treatment of proliferative sickle retinopathy. Indian J Ophthalmol. 2008; $56: 259-259$

111. Cai CX,Linz MO,Scott AW, Intravitreal bevacizumab for proliferative sickle retinopathy: a case series. J Vitreoretin Dis. 2017;2:32-38.

112. Rizzo S, Genovesi-Ebert F, Di Bartolo E, Vento A, Miniaci S, Williams G. Injection of intravitreal bevacizumab (Avastin) as a preoperative adjunct before vitrectomy surgery in the treatment of severe proliferative diabetic retinopathy (PDR). Graefes Arch Klin Exp Ophthalmol. 2008;246:837-42.
113. Moshiri A, Ha NK, Ko FS, Scott AW. Bevacizumab presurgical treatment for proliferative sickle-cell retinopathy-related retinal detachment. Retin Cases Brief Rep. 2013;7:204-5.

114. Oluleye TS. Pattern of presentation of sickle cell retinopathy in Ibadan. J Clin Exp Ophthalmol. 2012;3:257.

115. Van Geest RJ, Lesnik-Oberstein SY, Tan HS, Mura M, Goldschmeding R, Van Noorden CJF, et al. A shift in the balance of vascular endothelial growth factor and connective tissue growth factor by bevacizumab causes the angiofibrotic switch in proliferative diabetic retinopathy. Br J Ophthalmol. 2012;96:587.

116. Amissah-Arthur KN. Challenges with starting vitreoretinal services in the developing world. Nepal J Ophthalmol Biannu PeerRev Acad J Nepal Ophthalmic Soc Nepjoph. 2016;8:1-2.

117. Maneh N, Tchapbou Moyou DC, Nonon Saa KB, Amedome MK, Dzidzinyo K, Diatewa BM, et al. Risk factors for retinal detachment in Togo. Pan Afr Med J. 2017;28:74.

118. Osafo C, Raji YR, Burke D, Tayo BO, Tiffin N, Moxey-Mims $\mathrm{MM}$, et al. Human heredity and health (h3) in africa kidney disease research network: a focus on methods in Sub-Saharan Africa. Clin J Am Soc Nephrol. 2015;10:2279-87.

119. Elagouz M, Jyothi S, Gupta B, Sivaprasad S. Sickle cell disease and the eye: old and new concepts. Surv Ophthalmol. 2010;55:359-77.

120. Singh PC, Ballas SK. Emerging drugs for sickle cell anemia. Expert Opin Emerg Drugs. 2015;20:47-61.

121. Bernaudin F, Socie G, Kuentz M, Chevret S, Duval M, Bertrand Y, et al. Long-term results of related myeloablative stem-cell transplantation to cure sickle cell disease. Blood. 2007;110:2749-56.

122. Dever DP, Bak RO, Reinisch A, Camarena J, Washington G, Nicolas CE, et al. CRISPR/Cas $9 \beta$-globin gene targeting in human haematopoietic stem cells. Nature. 2016;539:384-9.

123. Ribeil J-A, Hacein-Bey-Abina S, Payen E, Magnani A, Semeraro $\mathrm{M}$, Magrin E, et al. Gene therapy in a patient with sickle cell disease. N Engl J Med. 2017;376:848-55.

124. Diallo DA, Guindo A. Sickle cell disease in sub-Saharan Africa: stakes and strategies for control of the disease. Curr Opin Hematol. 2014;21:210-4.

125. Ophthalmology TOE, 2015. Mobile phone funduscopy screening for retina manifestations of systemic disease in poor resource settings of sub-Sahara Africa. researchgate.net.

126. Yorston D, Jalali S. Retinal detachment in developing countries. Eye Lond Engl. 2002 Jul;16:353-8.

127. Sunday OT. Should posterior vitrectomy be made a priority in ophthalmic facilities of sub Sahara Africa? Open Ophthalmol J. 2013;7:1-3.

128. Booth C, Inusa B, Obaro SK. Infection in sickle cell disease: a review. Int J Infect Dis. 2010;14:e2-e12.

129. Kortuem K, Fasler K, Charnley A, Khambati H, Fasolo S, Katz $\mathrm{M}$, et al. Implementation of medical retina virtual clinics in a tertiary eye care referral centre. Br J Ophthalmol. 2018;

130. Mathew R, Bafiq R, Ramu J, Pearce E, Richardson M, Drasar E, et al. Spectral domain optical coherence tomography in patients with sickle cell disease. Br J Ophthalmol. 2015;99:967-72.

131. Alam M, Thapa D, Lim JI, Cao D, Yao X. Quantitative characteristics of sickle cell retinopathy in optical coherence tomography angiography. Biomed Opt Express. 2017;8:1741-13.

132. Acharya UR, Mookiah MRK, Koh JEW, Tan JH, Bhandary SV, Rao AK, et al. Automated screening system for retinal health using bi-dimensional empirical mode decomposition and integrated index. Comput Biol Med. 2016;75:54-62.

133. MTBC Bonanomi, Lavezzo, Sickle MM. Cell retinopathy: diagnosis and treatment. Arq Bras Oftalmol. 2013;76:320-27. 